\title{
Pengelolaan Keuangan Sederhana dan Kinerja
}

\author{
Diyan Lestari \\ Manajemen, Fakultas Bisnis Institut Teknologi dan Bisnis Kalbis \\ Jalan Pulomas Selatan Kav. 22, Jakarta Timur \\ Email: diyan.lestari@kalbis.ac.id
}

\begin{abstract}
The micro small medium enterprise (MSME) provide the largest contribution in Indonesia economy. Moreover, the number of MSME in Indonesia is larger than big companies. The better performance of MSME is expected to have better impact on economy. The community service activity was conducted with Finger and Chicks as the community service partner. Finger and Chicks is one of MSME in culinary business. There were several problems that should be tackled by Finger and Chicks team to improve their performance, especially related to financial management. The service community was conducted smoothly and expected to have better understanding in financial management and also improve their performance.
\end{abstract}

Keywords: financial management, performance, MSME

\begin{abstract}
Abstrak: UMKM pada dasarnya memberikan kontribusi yang besar bagi pertumbuhan ekonomi di Indonesia. Selain itu, proporsi UMKM di Indonesia jauh lebih besar dibandingkan dengan usaha besar. UMKM yang memiliki kinerja bagus tentunya diharapkan dapat menunjang perekonomian. Kegiatan pengabdian ini dilakukan dengan mitra PKM Finger and Chicks yang merupakan salah satu pelaku usaha di bidang kuliner. Beberapa permasalahan yang dihadapi oleh Finger and Chicks mengakibatkan kinerja Finger and Chicks belum optimal, khususnya terkait dengan pengelolaan keuangan. Pelaksanaan kegiatan PKM pada dasarnya berjalan lancar dan diharapkan dapat memberikan pemahaman yang lebih baik terkait dengan pengelolaan keuangan dan dapat meningkatkan kinerja mitra.
\end{abstract}

Kata kunci: kinera, pengelolaan keuangan, UMKM

\section{PENDAHULUAN}

Industri kreatif merupakan salah satu sektor yang terus bertumbuh. Selain itu, industri kreatif juga memiliki kontribusi yang besar bagi perekonomian, tercatat sebesar mengalami peningkatan dari tahun 2015 ke tahun 2017 dari 7.38\% bertumbuh menjadi $7.44 \%$ (Rachman, 2018). Sedangkan sub sektor kuliner memiliki kontribusi sebesar $41.4 \%$ dari total kontribusi perekonomian kreatif sebesar Rp 922 triliun pada 2016. Jumlah tersebut merupakan nilai tertinggi dibandingkan dengan 16 subsektor lainnya di Badan Ekonomi Kreatif (Agmasari, 2018). Sehingga, sektor kuliner yang maju juga akan membantu untuk mendorong perekonomian.

Pada dasarnya, sebagian besar pelaku usaha di Indonesia didominasi oleh Usaha Mikro Kecil Menengah, termasuk di dalamnya para pelaku usaha di sektor kuliner. Berdasarkan data dari Kementerian Koperasi dan UKM RI, pada tahun 2017 Usaha Mikro Kecil Menengah (UMKM) memiliki kontribusi terbesar jika dilihat dari jumlah unit atau para pelakunya, yaitu 99,99\% ( atau sekitar 62.9 juta unit) dari total pelaku usaha di Indonesia, sedangkan usaha besar hanya hanya memberikan kontribusi sebesar $0,01 \%$ atau 5400 unit usaha. Dari tingkat penyerapan tenaga kerja, usaha mikro memberikan kontribusi dalam penyerapan tenaga kerja sekitar 107,2 juta tenaga kerja $(89,2 \%)$, usaha kecil sebesar 5,7 juta tenaga kerja $(4,74 \%)$, usaha menengah ssekitar 3,73 juta (atau 3,11\%); sedangkan usaha besar memberikan kontribusi sekitar 3,58 juta jiwa. Hal tersebut menunjukkan bahwa total kontribusi UMKM dalam penyerapan tenaga kerja sekitar 97\%, sedangkan usaha besar hanya memiliki kontribusi $3 \%$ dari total penyerapan tenaga kerja nasional (Haryanti \& Hidayah, 2018).

Tingginya jumlah UMKM, khususnya usaha mikro dan juga kontribusinya dalam penyerapan tenaga kerja tentunya sangat penting bagi pemerintah dan juga pemangku kebijakan untuk meningkatkan kinerja UMKM guna memperkuat perekonomian. Akan tetapim seringkali UMKM khususnya para pelaku usaha mikro tidak memiliki sistem yang 
standar baik dalam tata kelola usahanya, strategi yang dijalankan termasuk di dalamnya strategi pemasaran, dan juga pengelolaan keuangannya yang merupakan salah satu instrumen penting untuk meningkatkan kinerja suatu usaha. Teknologi yang semakin maju tentunya dapat dioptimalkan penggunaannya bagi para pelaku usaha, khususnya untuk mengelola keuangan. Akan tetapi karena kurangnya pemahaman hal tersebut menyebabkan kurang optimalnya pemanfaatan berbagai platform teknologi untuk meningkatkan kinerja UMKM.

Pada awal tahun 2020, tercatat bahwa pengguna internet di Indonesia saat ini mencapai 175.4 juta jiwa dengan pentrasi penggunaannya mencapai $64 \%$ yang berarti bahwa $64 \%$ masyarakat Indonesia sudah memiliki akses terhadap internet. Angka tersebut meningkat sekitar $17 \%$ atau 25 juta dibandingkan dengan tahun sebelumnya (Pertiwi, 2020). Hal tersebut menunjukkan, bahwa pada dasarnya akses informasi dapat diakses dengan cepat oleh berbagai lapisan masyarakat termasuk para pelaku usaha untuk mencari berbagai solusi dalam meningkatkan usahanya, termasuk di dalamnya terkait dengan pengelolaan keuangan, misalnya dengan mencari berbagai aplikasi yang dapat digunakan untuk membantu pengelolaan keuangan maupun berbagai informasi pada berbagai platform yang memberikan informasi mengenai tata cara pengelolaan keuangan yang sesuai.

Fatwitawati (2018: 225) menyatakan bahwa pengelolaan keuangan merupakan salah satu faktor penting untuk meningkatkan kinerja suatu perusahaan, karena dengan pengelolaan keuangan yang baik pelaku usaha dapat melakukan identifikasi jumlah kekayaan dan bagaimana mengoptimalkannya, melakukan analisa kinerja keuangan yang dapat dilihat dari data penjualan, maupun laba yang diperoleh, mengetahui posisi dana, membuat anggaran (termasuk di dalamnya berbagai anggaran yang digunakan untuk membiayai kegiatan usaha), dan juga tentunya perhitungan pajak. Suindari \& Juniariani (2020: 148) menyebutkan bahwa semakin baik pengelolaan keuangan pelaku usaha, maka akan berdampak positif terhadap kinerjanya.

Finger and Chicks merupakan salah satu resto yang memiliki konsep western food yang tentunya merupakan usaha yang bergerak pada sektor kuliner yang berlokasi di Jakarta Timur. Pada dasarnya, Finger and Chicks menyediakan menu yang unik jika dibandingkan dengan produk resto yang lain karena ayamnya dibuat dengan bumbu khusus dan nasinya dibuat khusus dengan menggunakan mentega. Akan tetapi, terdapat beberapa kendala dalam kegiatan usahanya salah satunya adalah kurangnya dalam melakukan identifikasi aliran kas usahanya. Oleh karena itu, penting bagi Finger and Chicks untuk mulai memperhatikan pengelolaan keuangannya.

\section{METODE PELAKSANAAN}

Dalam kegiatan Pengabdian Kepada Masyarakat, sangat penting untuk melakukan observasi guna menggali berbagai permasalahan mitra dan untuk dapat memberikan solusi yang sesuai dengan permasalahan mitra. Setelah melakukan berbagai pendekatan dan juga observasi kepada mitra, dalam hal ini adalah Finger and Chicks maka untuk memberikan pemahaman lebih baik mengenai pengelolaan keuangan UMKM akan dilakukan pelatihan secara interaktif.

Sebelum melakukan Kegiatan Pengabdian Kepada Masyarakat berupa berbagai pelatihan yang diharapkan dapat menunjang atau meningkatkan kinerja Mitra PKM, maka dilakukan berbagai aktivitas yang terkait dengan penelitian kualitatif di mana dilakukan observasi atau pengamatan, dokumentasi, wawancara, dan tentunya teknik triangulasi. Penelitian kualitatif merupakan salah satu jenis penelitian yang sudah digunakan secara luas, termasuk dalam penelitian sosial. Dalam penelitian kualitatif pada dasarnya dipengaruhi oleh berbagai paradigm dan fenomena sosial.

Nugrahani (2014) menyatakan bahwa para peneliti pada penelitian kualitatif lebih menekankan pada sifat realita yang pada dasarnya terbangun secara sosial, juga memiliki hubungan erat antara para penelitinya dengan subjek yang diteliti serta berbagai tekanan situasi yang membentuk dan ada pada aktivitas penelitian. Selain itu, peneliti pada penelitian kualitatif cenderung mementingkan sifat penelitian dengan berbagai nilai-nilainya melalui pencarian jawaban dari pertanyaan yang terkait dengan berbagai pengalaman sosial dan makna atas pengalaman sosial tersebut. Sedangkan penelitian kuantitatif lebih menitikberatkan pada pengukuran dan melakukan analisis sebab akibat dari berbagai variabel dan tidak fokus pada proses mencari keterkaitan hubungan dari variabel tersebut.

Dalam penelitian kualitatif, paling tidak terdapat 5 jenis metode yang sering digunakan, antara lain: observasi, analisa percakapan atau analisa dari hasil wawancara, analisa wacana, analisa isi, dan pengambilan data ethnografis (Somantri, 2005: 59). Di mana observasi biasanya identik dengan bagaimana 
peneliti langsung terlibat dalam setting social dan melakukan pengamatan secara langsung mengenai apa yang diteliti. Analisa percakapan lebih fokus pada interaksi, komunikasi dan wawancara. Analisa wacana atau disclosure analysis merupakan analisa yang menitikberatkan pada penggunaan bahasa. Analisa isi atau content analysis merupakan penelitian yang fokus pada analisa pada dokumen-dokumen dan menganalisa isinya. Sedangkan pengambilan data ethnografis lebih fokus pada penggalian tekstur dan berbagai pengalaman selektif.

Pada kegiatan pengabdian kepada masyarakat dengan mitra UMKM Finger and Chicks, dilakukan penggalian permasalahan melalui observasi, wawancara yang dilakukan dengan pemilik dan karyawan Finger and Chicks, dan juga dokumentasi. Wawancara dilakukan secara langsung dengan harapan memperoleh berbagai insight mengenai berbagai permasalahan dan juga dapat memberikan solusi sesuai dengan kebutuhan mitra PKM. Observasi dilakukan untuk melakukan pengamatan situasi sosial mitra sehingga peneliti dapat memperoleh gambaran secara langsung mengenai kondisi tempat usaha dan bagaimana praktek tata kelola khususnya terkait dengan pengelolaan keuangan usaha. Sedangkan dokumentasi dilakukan untuk membantu melengkapi berbagai data yang sudah diperoleh melalui kegiatan observasi dan wawancara.

\section{A. Sumber Data}

Kegiatan Pengabdian Kepada Masyarakat ini dilakukan dengan menggunakan metode penelitian kualitatif dan data penelitian yang digunakan adalah data primer. Data primer merupakan data yang diperoleh peneliti secara langsung yang diharapkan dapat memberikan gambaran secara langsung dalam menggali berbagai permasalahan yang dihadapi oleh mitra PKM dan mampu memberikan berbagai solusi yang sesuai kebutuhan mitra. Dalam kegiatan penelitian, terutama dalam melakukan wawancara, peneliti telah melakukan pengelompokan atau pengklasifikasikan responden atau informan yang nantinya akan diteliti, sebagai berikut:

1. Pemilik Usaha, Bapak Muhammad Arbi.

2. Staf yang terdiri dari chef, kasir, dan 3 orang pelayan.

Selain itu, pada pelaksanaan kegiatan pengabdia kepada masyarakat ini juga menggunakan data sekunder yang merupakan data yang diperoleh dari sumber yang sudah diolah atau data yang sudah ada. Data sekunder dalam penelitian ini digunakna untuk memberikan berbagai kajian literatur dan juga berbagai data pendukung untuk memberikan penjelasan detail mengenai berbagai fenomena dan permasalahan yang diteliti.

\section{B. Fokus dan Lokasi Penelitian}

Kegiatan Pengabdian Kepada Masyarakat pada dasarnya merupakan suatu kegiatan untuk memberikan pemahaman lebih dan sumbangsih ilmu pengetahuan kepada masyarakat. Untuk membahas berbagai kegiatan yang dilakukan dan juga penelitian yang dilakukan dalam kegiatan PKM, maka terdapat beberapa batasan masalah yang menjadi fokus dalam pembahasan penelitian. Kegiatan PKM dilakukan fokus untuk menggali berbagai permasalahan yang dihadapi oleh mitra dan memberikan solusi untuk menjawab masalah mitra yang dalam hal ini adalah Resto Finger \& Chicks, yaitu terkait dengan pengelolaan keuangan yang sangat sederhana pada UMKM tersebut.

Lokasi kegiatan pengabdian kepada masyarakat, atau dalam hal ini juga terkait dengan penelitian kualitatif untuk menggali masalah dan memberikan solusi, dilakukan di tempat mitra PKM, yaitu di resto Finger and Chicks, Buaran, Jakarta Timur. Hal tersebut dilakukan untuk dapat langsung berkomunikasi dengan pemilik dan staf sebagai responden peneliti dan juga melakukan observasi langsung ke pada mitra PKM.

\section{Finger and Chicks}

Finger and Chicks merupakan resto yang memiliki konsep western food, berlokasi di Jalan Radin Inten II Blok B Kav 21, Depan SMK N 48 Jakarta, Jakarta Timur, RT.1/RW.14, Klender, Duren Sawit, DKI Jakarta, Daerah Khusus Ibukota Jakarta 13470 dekat dengan pusat perbelanjaan Buaran Plaza dan tempat kuliner lain dengan lokasi yang cukup strategis. Suasana resto cukup nyaman dengan variasi makanan yang menarik dan ditawarkan dengan harga yang terjangkau. Akan tetapi, Finger and Chicks belum melakukan pengelolaan keuangan secara tersistematis.

Karyawan Finger and Chicks pada dasarnya ramah dan cukup membantu para pelanggan. Suasana resto yang nyaman juga diimbangi dengan kondisi yang rapi dan bersih. Selain itu, persaingan di bidang kuliner di daerah Buaran (Jalan Radin Inten) memang terbilang cukup sengit, dengan memperhatikan adanya mall yang juga menawarkan berbagai produk kuliner, juga resto-resto di sekitar Jalan Raden Inten. Untuk itu, perlu adanya pengelolaan keuangan yang tepat guna meningkatkan kinerja UMKM, 
khususnya Finger and Chicks. Melakukan analisa kondisi keuangan perusahaan, rugi laba, dan aliran kas sangatlah penting untuk mendukung berbagai strategi perusahaan dalam memenangkan persaingan, misalnya terkait dengan pendanaan sehingga mengetahui berbagai alternatif pendanaan dan berbagai biaya yang muncul karena pemilihan salah satu alternatif pendanaan. Selain itu, penggunaan biaya termasuk biaya marketing juga lebih dapat diukur efektifitasnya sehingga diharapkan dapat memberikan insight untuk melakukan pengelolaan yang lebih rapi pada berbagai strategi perusahaan.

\section{Profil Finger and Chicks}

Berikut ini merupakan profil dari usaha yang menjadi mitra dalam kegiatan Pengabdian Kepada Masyarakat yang datanya kami peroleh dari Pak Muhammad Arbi selaku Pemilik Finger and Chicks Nama Usaha Mitra : Finger and Chicks Nama Pemilik Usaha : Muhammad Arbi Alamat Usaha Mitra : Jalan Radin Inten II Blok B

Kav 21, Depan SMK N 48 Jakarta, Jakarta Timur, RT.1/RW.14, Klender, Duren Sawit, DKI Jakarta, Daerah Khusus Ibukota Jakarta 13470 Telp. : 0822-2111-27679/ 0812$\underline{8917-1867}$

Email : fingerchicks@gmail.com Website/Media Sosial : @Fingerandchicks

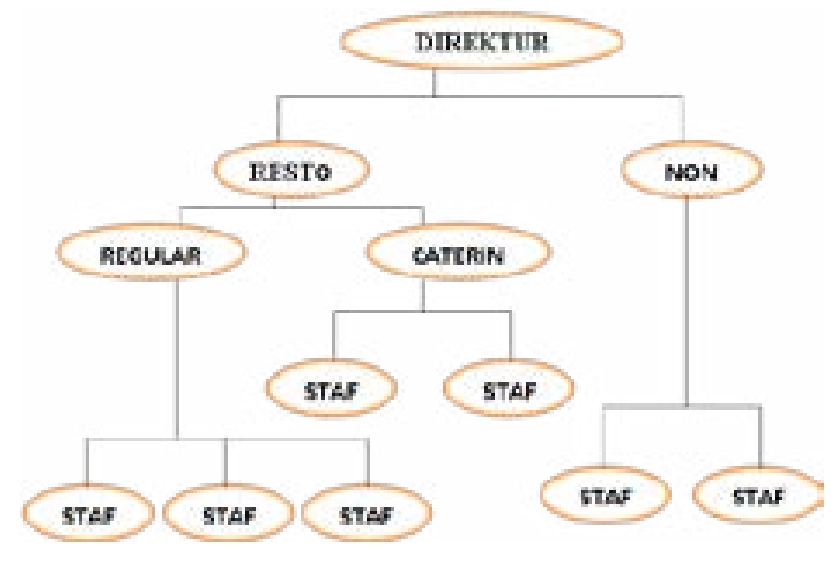

Gambar 1 Struktur Organisasi

Gambar 1 menjelaskan mengenai struktur organisasi Finger and Chicks di mana Muhammad Arbi selaku pemilik Finger and Chicks dan dibantu dengan beberapa stafnya untuk mengelola resto dengan berbagai job deskNya. Meskipun ada beberapa staf yang mengerjakan beberapa pekerjaan.

\section{E. Kinerja}

Kinerja seringkali merupakan tolok ukur untuk melakukan judgement mengenai keberhasilan sebuah bisnis. Kinerja atau performance adalah cerminan berbagai upaya yang dilakukan oleh pengelola bisnis (manajemen) dalam menjalankan usaha. Kinerja, pada dasarnya dapat diukur melalui berbagai indikator, misalnya dapat dilihat dari sisi sumber daya manusia mengenai bagaimana karyawan merasa nyaman ketika bekerja, dan juga lingkungan kerja yang kondusif. Dari sisi marketing, terkait dengan pencapaian penjualan dan bagaimana strategi marketing yang dirumuskan dapat memperoleh impact yang luas sesuai dengan yang sudah disasarkan.

Akan tetapi, secara umum kinerja diukur dengan menggunakan ukuran kinerja keuangan. Hal tersebut karena pengukuran kinerja berdasarkan ukuran keuangan lebih mudah dilakukan. Mengukur dengan menggunakan angka dan laporan keuangan akan lebih mudah untuk membandingkan berbagai biaya, penghasilan, kerugian, maupun keuntungan yang diperoleh dari hasil usaha. Pelaku usaha dapat dengan mudah melakukan pengecekan nilai atau angka yang bertambah atau berkurang sehingga dapat segera dilakukan tindakan perbaikan atas strategi yang sudah dijalankan.

\section{HASIL DAN PEMBAHASAN}

\section{A. Pendidikan Mitra}

Pada dasarnya pemilik Resto Finger and Chicks yang merupakan Mitra PKM memiliki tingkat pendidikan yang cukup baik, sehingga dapat dengan baik dalam membuat konsep dan merencanakan bisnisnya. Akan tetapi, pemilik seringkali kesulitan memberikan edukasi kepada para staf untuk lebih detail dan teliti dalam melakukan berbagai pekerjaan, khususnya dalam pengelolaan keuangan. Setiap data akan sangat bermakna terutama jika dikaitkan dengan pengelolaan keuangan.

\section{B. Permasalahan Mitra}

keuangan menjadi patokan dalam menjalankan usaha, seringkali pemilik usaha harus membuat strategi agar perputaran uang UMKM ini dapat berjalan dengan efektif dan efesien. Pemilik UMKM ini mengatakan bahwa untuk mengembangkan usaha harus membutuhkan modal yang cukup besar. Pemilik usaha memafaatkan penjualan dan investor untuk menghimpun dana, tetapi untuk saat ini pemilik UMKM ini merasa kurang dalam dana akibatnya banyak divisi yang tidak berjalan dengan baik akibat dari dana yang kurang.

Selain itu, terdapat beberapa hal penting terkait dengan pengelolaan keuangan yang dilakukan oleh mitra PKM. Misalnya, sering terjadi kesalahan dalam 
melakukan pencatatan keuangan yang dilakukan oleh staf. Hal tersebut tentunya akan berdampak pada bagaimana mengukur berbagai aktivitas yang terjadi dalam melakukan pengelolaan bisnis. Kurangnya pengelolaan keuangan juga dapat mengakibatkan kinerjanya yang memburuk karena salahnya perhitungan biaya. Hal tersebut tercatat bahwa beberapa kali resto mengalami kerugian dibandingkan dengan laba yang dihasilkan.

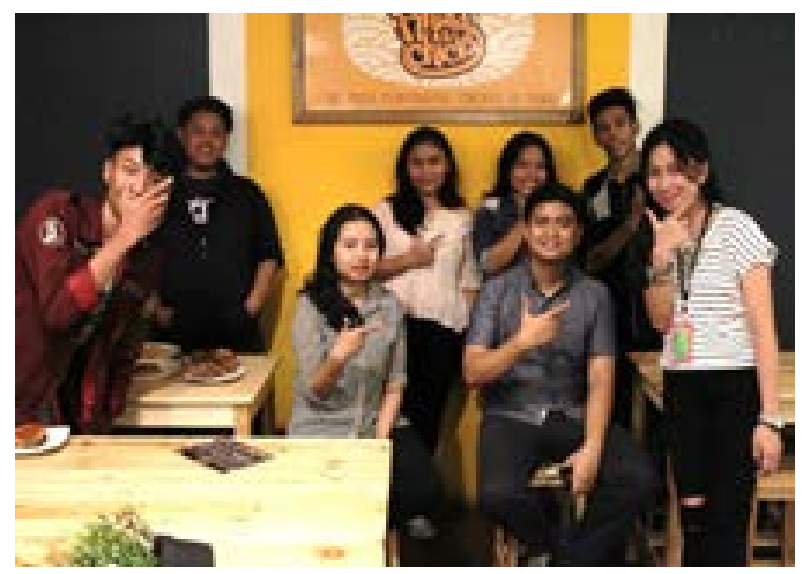

Gambar 2 Diskusi dan Pelatihan

Gambar 2 menggambarkan mengenai pelaksanaan kegiatan pengabdian kepada masyarakat dengan mitra PKM Finger and Chicks. Para peserta cukup aktif dan bersemangat untuk mengikuti pelatihan yang diharapkan dapat membantu meningkatkan kinerja Finger and Chicks.

Pelatihan pengelolaan keuangan sederhana yang dilakukan antara lain meliputi arti penting melakukan pengelolaan keuangan, jenis-jenis laporan keuangan, dan berlatih membuat laporan keuangan sederhana untuk meminimalkan adanya kesalahan pencatatan dalam laporan keuangan.

Metode yang digunakan dalam kegiatan pengabdian ini berupa penyampaian materi dan menggunakan metode, yaitu dengan memberikan program pelatihan interaktif dengan topik mengenai meningkatkan kinerja bisnis melalui pengelolaan keuangan yang tepat. Pelatihan tersebut meliputi rangkaian materi sebagai berikut: 1) Pendefinisian manajemen keuangan; b) Arti penting laporan keuangan; c) Jenis-jenis laporan keuangan; dan Pelatihan pembuatan laporan keuangan yang sangat sederhana.

\section{Produk Kegiatan yang Bermanfaat}

Setelah dilakukan kegiatan PKM, dilakukan evaluasi terhadap kegiatan PKM untuk melihat apakah pelatihan memberikan indikator keberhasilan. Evaluasi yang dilakukan adalah dengan menerima feedback dari yang menjadi mitra kita dan kegiatan ini dinilai berhasil oleh mitra berdasarkan target dan capaian. Berikut merupakan hasil evaluasi kegiatan PKM: 1) Program yang diberikan sesuai dengan kebutuhan mitra dan menjawab permasalah mitra yang dilihat dari sisi pemasaran dan keuangan; 2) Program yang diberikan sesuai dengan trend saat ini terkait dengan kegiatan promosi secara digital dan pengelolaan keuangan; dan 3) Program dilakukan secara sistematis dan akan dilakukan secara bertahap.

\section{SIMPULAN}

Dengan pelatihan ini manfaat yang akan diperoleh diantaranya: Kerjasama dengan mitra PKM yang dalam hal ini adalah Finger and Chicks; Para peserta pelatihan memperoleh wawasan mengenai pentingnya kegiatan promosi secara digital yang dapat meningkatkan kinerja UKM; dan Para peserta pelatihan memperoleh wawasan mengenai pentingnya pengelolaan keuangan yang dapat meningkatkan kinerja UKM.

\section{DAFTAR RUJUKAN}

Agmasari, S. (2018, February 6). Industri Kuliner, Penopang Tertinggi Perekonomian Kreatif di Indonesia. Dipetik Maret 10, 2018, dari https://travel.kompas.com: https:// travel.kompas.com/read/2018/02/06/185000027/ industri-kuliner-penopang-tertinggi-perekonomiankreatif-di-indonesia

Fatwitawati, R. (2018). Pengelolaan Keuangan Bagi Usaha Mikro Kecil Menengah (UMKM) di Kelurahan Airputih Kecamatan Tampan Kota Pekanbaru. Sembadha, Volume 01, Edisi 01, 225-229.

Haryanti, D. M., \& Hidayah, I. (2018). Potret UMKM Indonesia: Si Kecil yang Berperan Besar. Retrieved February 3, 2020, from www.ukmindonesia.id: https:// www.ukmindonesia.id/baca-artikel/62

Nugrahani, F. (2014). Metode Penelitian Kualitatif: dalam Penelitian Pendidikan Bahasa. LPPM Universitas Veteran Bangun Nusantara.

Pertiwi, W. K. (2020). Penetrasi Internet di Indonesia Capai 64 Persen. Retrieved Maret 16, 2020, from tekno.kompas.com: https://tekno.kompas.com/ $\mathrm{read} / 2020 / 02 / 20 / 14090017 /$ penetrasi-internet-diindonesia-capai-64-persen

Rachman, F. F. (2018, February 27). Sumbangan Ekonomi Kreatif ke PDB RI Naik Rp 70 Triliun/Tahun. Dipetik Maret 19, 2018, dari https://finance.detik.com: https:// finance.detik.com/berita-ekonomi-bisnis/d-3888781/ sumbangan-ekonomi-kreatif-ke-pdb-ri-naik-rp-70triliuntahun

Somantri, G. R. (2005). Memahami Metode Kualitatif. 
Makara, Sosial Humaniora, Vol. 9, No. 2, 57-65.

Suindari, N. M., \& Juniariani, N. M. (2020). Pengelolaan Keuangan, Kompetensi Sumber Daya Manusia dan Strategi Pemasaran dalam Mengukur Kinerja Usaha Mikro Kecil Menengah (UMKM). Jurnal KRISNA:

Kumpulan Riset Akuntansi; Vol. 11, No. 2, 148-154. 